\title{
Commentary on K. M. Bethel, Progress Report on the Project
}

\author{
Linda A. Davis \\ The College of The Bahamas ${ }^{1}$
}

\section{Abstract}

Dr Keva M. Bethel, President Emerita of The College of The Bahamas was appointed by The College as Scholar-in-Residence from August 1, 2009 to September 30, 2011. Her brief was to write a book on the history of post-secondary education in The Bahamas, with particular reference to the history of The College of The Bahamas. The report of progress on this assignment, the subject of this commentary, builds upon her preliminary findings, covering the period from August 1, 2009 to April 30, 2010, written before her death in 2011, and published in this volume of the International Journal of Bahamian Studies.

\section{INTRODUCTION}

The short report provides a summary of a literature search, the proposed approach that she would take to frame the writing, selected preliminary findings, a brief description of early efforts at teacher training, dating back to the Education Act of 1821, followed by the historical beginning of technical and vocational studies. The list of sources noted in the progress report includes newspapers, books, theses and dissertations, and official documents (legislation, Board of Education minutes, documents from The College of The Bahamas, special reports and papers). Reference was also made to documents found among former College Council Chairman (1975-1995), the Rt. Rev. Michael H. Eldon's personal collection. Before providing brief concluding comments, the President Emerita referenced other activities in which she was engaged, including being available for interviews, serving as a guest lecturer and as a resource on educational matters.
President Emerita Bethel left us too soon, unable to complete this important work, and thus contribute to a useful lens through which we might review the evolution of The College of The Bahamas and its current transition to the University of The Bahamas. No stranger to the education landscape in The Bahamas, or the region, Dr Bethel wrote a doctoral dissertation (1981) focused on the teacher training programmes offered by The College of The Bahamas. Also, she either chaired or served on several commissions focussing on educational provision in The Bahamas. Some of the most noteworthy of these were, arguably, the Master Plan for Post-Secondary Education in The Bahamas (1992), the National Task Force on Education (1994, better known as the "Bethel Report"), and the Final Report of the Ad Hoc Advisory Committee on Governance (2007). The focus of the current paper is a review of the analytic lens used by Bethel in the last piece that she

\footnotetext{
${ }^{1}$ Linda A. Davis, Provost, The College of The Bahamas, P.O. Box N-4912, Nassau, Bahamas.

E-mail: linda.davis@cob.edu.bs

APA reference: Davis. L. A. (2016). Commentary on K. M. Bethel, Progress Report on the Project. The International Journal of Bahamian Studies, 22, 74-82. http://dx.doi.org/10.15362/ijbs.v22i0.275
}

(c) L. A. Davis, 2016. Journal compilation (c)The International Journal of Bahamian Studies, 2016 
authored in her role as Scholar-in-Residence, examining the currency of that lens as The College of The Bahamas transitions to the University of The Bahamas.

Bethel posits that the fundamental premise of the work in which she was engaged, and for which she was contracted was that

the establishment of The College of The Bahamas in 1974, with the intent, form and scope of responsibilities identified for it, represented not only an important purposeful event but also, even more profoundly perhaps, a quantum leap in a process of educational development in The Bahamas that had spanned many generations" (Bethel, 2016, p. 61).

Despite this, as chronicled by Bethel, the pace of educational development in the archipelago had advanced very slowly, "and in fits and starts, reflecting vividly the 'boom and bust' nature of the Bahamian economy and social experience, as well as the particular imperatives at work in the society at any given point in time" (Bethel, 2016, p. 61). Her analysis led her to conclude that many of the issues of the past, revealed through her review of archival documents available, persist today. Such concerns include "less than adequate funding, overly restrictive bureaucratic procedures and processes and external control that impinge heavily upon the autonomous functioning of the institution" (Bethel, 2016, p. 62).

As Bethel notes, the thematic framework that informs this conclusion is drawn from The College's mission: academic education; teacher education; technical and vocational studies; business studies; other professional studies; adult and continuing education. She further suggests that organisational, governance, financial, physical and, particularly, human resource elements, must be considered as well. It is this framework on which the current reviewer builds, in the words of President Emerita Bethel, bridging these "assumptions (and presumptions) we bring to our view of where we are and from where we have come...[hopefully] contribut[ing] to [and] minimizing the influence of some of these" (Bethel, 2016, p. 73).

\section{FUNDING}

Bethel's brief, but pointed, review of inadequate funding of educational provision of post-secondary education in The Bahamas leading up to the establishment of The College of The Bahamas, through an Act of Parliament in 1974 is instructive. The institution, born of the amalgamation of The Bahamas Teachers College, San Salvador Teachers' College, C. R. Walker Technical College and the sixth form programme of the Government High School, created a major post-independence icon that, arguably, would define the educational landscape of the nation. The challenges, characteristic of the previous eras as outlined by Bethel, persist with reference specifically to the underfunding up to, and beyond, the 20th century. As Bethel argues, while there were many noteworthy proposals advanced by the Board of Education and/or independent sector, including a High School in New Providence (1804); the King's College School (1834); The Grammar School (1854); The Nassau Grammar School (1865); and St. Hilda's School for Girls (1886), due to the lack of funding, none realized the full benefits envisioned. The funding was just not forthcoming from the House of Assembly.

The same held true for the troubled technical and vocational sector. Although noted as a means through which a curriculum of a "more necessary, practical and valuable kind than offered in the regular schools", the Board of Education felt that "there were still many places in the colony where there was not yet any provision for education and the diversion of scarce resources for such a purpose would be unfair" (Board of Education Minutes, 
October 1896, cited in Bethel, 2016, p. 71). Even in the instance of the Bahama Collegiate (Nassau) established in 1871, which later evolved into Queen's College in 1890, as well as the publicly funded Government High School, founded in 1925, according to Bethel, "one can only conclude, as it has often been asserted, that education for the masses of the people was not seen as a priority" (p. 65).

\section{Funding for $C O B$}

An examination then of funding support of the now premiere national institution, to be the University of The Bahamas, reveals comparable trends. Budget estimates record that from 1998/99 through 2014/15, government support of The College of The Bahamas has ranged from \$13,325,930 $(1998 / 99)$ to $\$ 27,365,690$ (2008/09). The 2014/15 level records a decrease to $\$ 18,270,826$, a $15 \%$ decrease over the previous year (W. J. Fielding, personal communication, April 19, 2016). Furthermore, as Figure 1 clearly illustrates, when one adjusts the government support for the Consumer Price Index, the purchasing power of the 2014/15 grant is similar to that in $1998 / 99$.

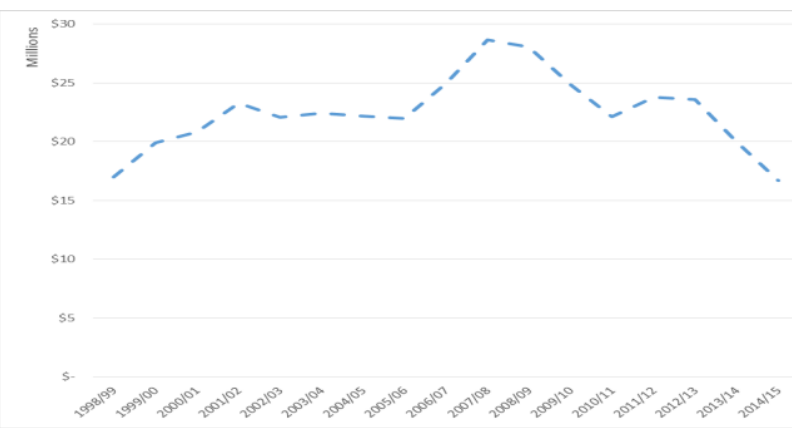

Figure 1: Government support adjusted for Consumer Price Index. Source: Fielding, 2015.

The low levels of funding obtain despite the fact that the institution has had to increase its services and expand infrastructure. Capital improvements of note include the Harry C. Moore Library and Information Centre opened in 2011; the new Northern Bahamas Campus, with projected residence facilities to house 55 students, a cafeteria, study facilities, a library and technology center opened in 2014; the Franklyn R. Wilson Graduate Centre, forecast for completion in 2017; and the start of construction of the G. T. R. Campbell Small Island Sustainability Complex on the Oakes Field Campus in 2016.

Also, the student enrolment in the institution's approximately 40 undergraduate programmes and over 20 associate degree offerings has increased, as has its alumni base, to over 11,000 (College of The Bahamas, 2010). This increased enrolment coupled with the growing responsibility and expectation of the university's mission, "to support and drive national development through teaching, research \& innovation and service to the community," must be highlighted (College of The Bahamas, 2009, p. 17).

Of particular note are the strategic partnerships and initiatives that ought to be vested in the university, as well as permitting the institution the authority to pursue, including the funding and resources required to sustain such efforts. The underfunded Marine and Environmental Studies Institute, created in 2005, points up that although conceived as an initiative that was laudable, unless funding is identified to attract and retain research-focused faculty and sustain efforts so critical as marine and environmental research initiatives, the vision of the university will be challenged. Indeed, the originally conceived idea was that the Marine and Environmental Studies Institute would:

provide leadership in programme development and research initiatives so as to take full advantage of The College/University's location in a small island state and year-round access to the unique sub-tropical ecosystems of the coastal, coral reefs, mangrove and sea grass communities in The Bahamas (College of The Bahamas, 2007). 
More recently conceived initiatives include the new partnership between The College of The Bahamas and The Bahamas Agriculture and Marine Science Institute in Andros; the monitoring and evaluation role envisioned to be played by The College/University of The Bahamas in the National Development Plan; and the proposed partnership between the Northern Campus of The College/University and the Mediterranean Shipping Company, through the establishment of a MSC Seafarers Technical School on Grand Bahama (Christie, 2016). In fact, some have suggested that even larger investments in higher education are warranted; for in addition to driving and sustaining the economy, graduates "consume more goods and services, are less reliant on public services, highlighting benefits far beyond the initial government investment" (Fielding, 2014, p. 9).

The government grant per student highlights another area worth analysing. This grant to The College since 1998/99, adjusted for the Consumer Price Index, has decreased from $\$ 4,570$ to around $\$ 3,500$, representing a decline of approximately $23 \%$ since 1998/99, and a decrease of $48 \%$ from 2007/08 (Figure 2).

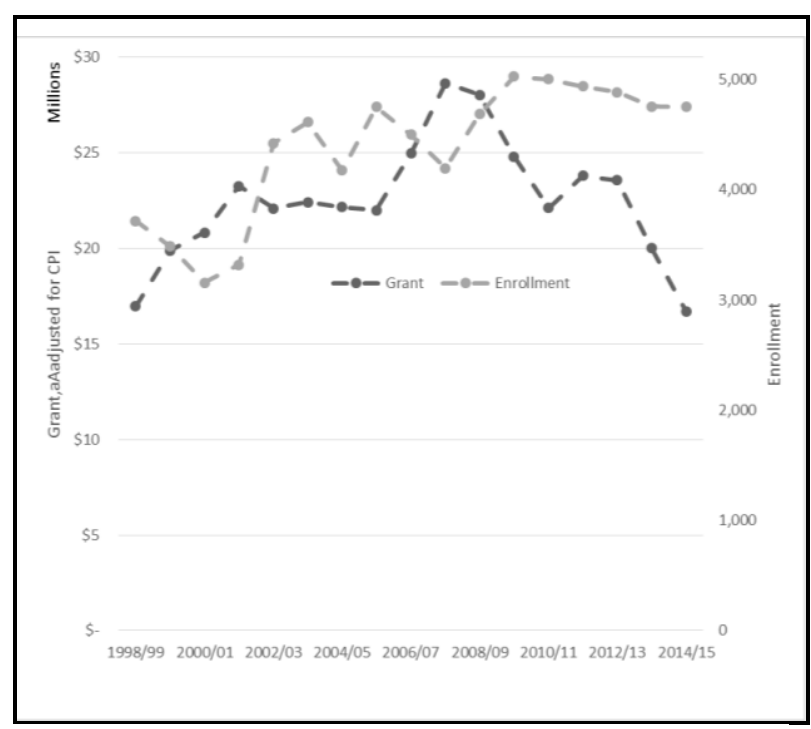

Figure 2: Enrolment and government grant, adjusted for the Consumer Price Index, 1998/99 to 2014/15. Source: Fielding, 2015.
In her presentation to the Prime Minster in 2006, proposing an increase in the per-student support, President of The College of The Bahamas, Janyne Hodder, highlighted the finding that The College spent less per student than institutions in other locations (Figure 3). The proposed goal at the time was $\$ 10,000$ per student, projected for implementation in 2010. Unfortunately, the closest The College came to this level of funding was when it spent $\$ 9,862$, in 2012 .

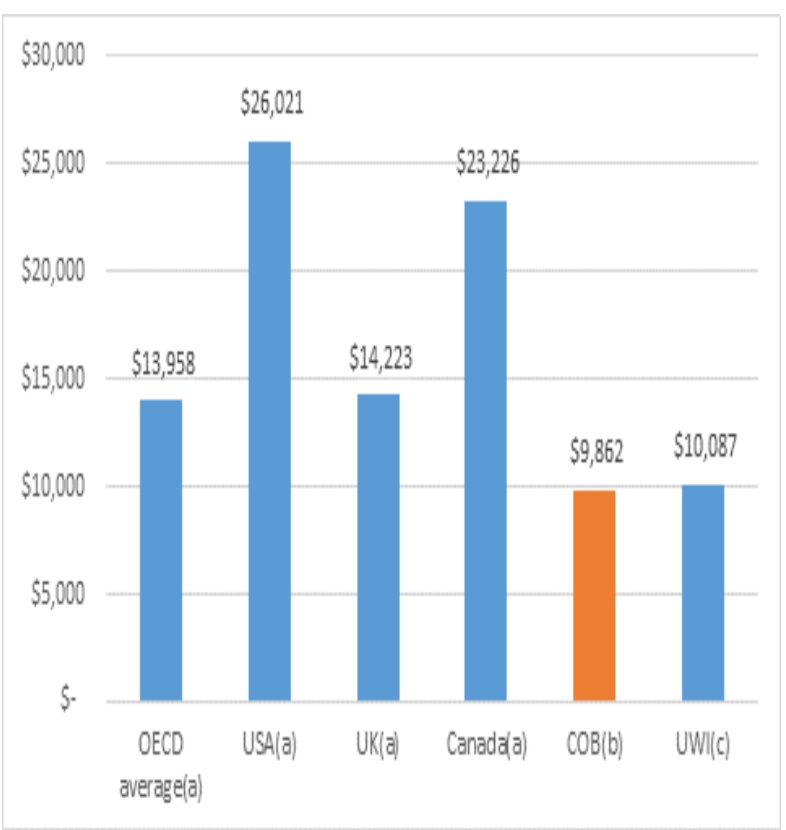

Figure 3: Average amount (\$) spent by institutions per student in 2012

Sources: ${ }^{\mathrm{a} O E C D . ~(2015) . ~ E d u c a t i o n ~ a t ~ a ~ g l a n c e ~ 2015: ~}$ OECD indicators. Retrieved from Table B1.1a http://download.ei-ie.org/Docs/WebDepot /EaG2015_EN.pdf ; 'COB. (2013). Government subvention: Implications and strategies. Retrieved from http://www.cob.edu.bs/nationalbudget /GovtSubventionImplications.pdf , 'UWI estimated.

These trends are critical when one considers required funding to sustain the projected growth, as well as to enhance additional requirements as obtain with the transition to university. Such funding includes, but is not limited to, the support required to propel an active research agenda and to attract and retain the kind of faculty and professional 
staff needed to accomplish such goals. In fact, although recommended within the context of further research required to inform issues related to crime and violence in The Bahamas, Sutton (2016) argues that there is a need for larger investments in even basic research, along with "establishing partnerships with academic institutions such as The College of The Bahamas and other regional and international academics and practitioners" (p. 87). Such investments, too, ought to allow for structuring within the faculty profile to permit allocation of focused efforts on each of the pillars, individually and collectively, of the university-research, service and teaching-in a deliberate and intentional fashion, as the university sets benchmarks and accomplishments in each of these areas. This conceptualization might, in turn, adjusted for context, be compared to data such as that collected through such surveys as the Faculty Survey of Student Engagement (FSSE), "designed to measure instructional staff expectations for student engagement in educational practices that are empirically linked with high levels of learning and development" (Indiana University Center for Postsecondary Research, 2016).

\section{Other Sources of Funding}

Indeed, The College of The Bahamas has had to rely on funding sources beyond that provided by the government grant to cover its operational expenses. The challenge in the transition to university will be whether this effort can be sustained, and in fact, increase as the need becomes even greater (Figure 4 and Table 1).

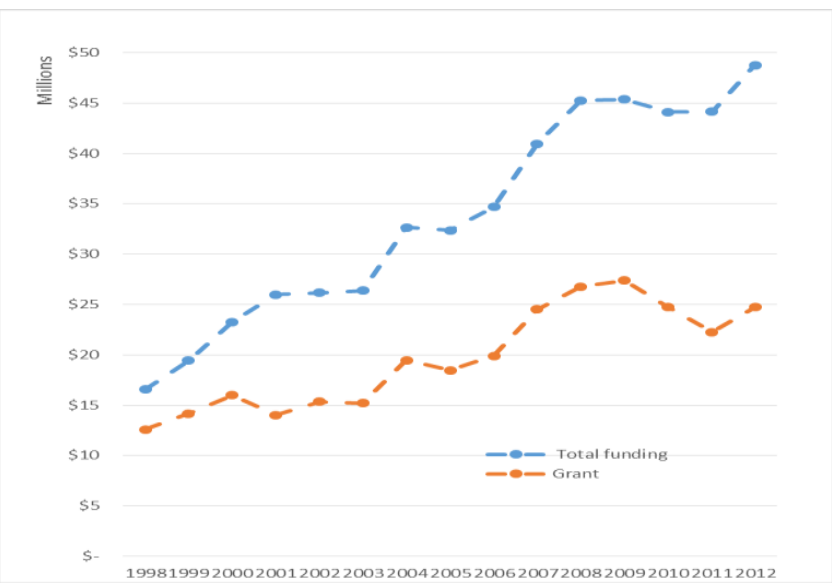

Figure 4: Total funding and government grant to The College.

Source: Fielding, 2015.

Table 1. Funding Sources

\begin{tabular}{l|c|c|c|c}
$\begin{array}{l}\text { FUNDING } \\
\text { SOURCE }\end{array}$ & $\begin{array}{l}2009 \\
\text { (Audited) }\end{array}$ & \multicolumn{1}{l}{$\begin{array}{l}2010 \\
\text { (Unaudited) }\end{array}$} & $\begin{array}{l}\text { 2011 } \\
\text { (Unaudited) }\end{array}$ & $\begin{array}{l}2012 \\
\text { (Unaudited) }\end{array}$ \\
\hline $\begin{array}{l}\text { Government } \\
\text { grant }\end{array}$ & $60 \%$ & $56 \%$ & $52 \%$ & $51 \%$ \\
\hline $\begin{array}{l}\text { Tuition \& } \\
\text { fees }\end{array}$ & $33 \%$ & $38 \%$ & $38 \%$ & $43 \%$ \\
\hline $\begin{array}{l}\text { Donations } \\
\text { Sales \& } \\
\text { services of } \\
\text { auxiliary } \\
\text { departments }\end{array}$ & 0 & 0 & $3 \%$ & $1 \%$ \\
\hline $\begin{array}{l}\text { Other } \\
\text { sources, net }\end{array}$ & $1 \%$ & $1 \%$ & $1 \%$ & 0 \\
\hline $\begin{array}{l}\text { Interest } \\
\text { income }\end{array}$ & 0 & 0 & $0 \%$ & 0 \\
\hline $\begin{array}{l}\text { Amortization } \\
\text { of deferred } \\
\text { grants }\end{array}$ & 0 & 0 & $3 \%$ & $1 \%$ \\
\hline \begin{tabular}{l} 
Total \\
\hline
\end{tabular} & $\$ 45.2 \mathrm{M}$ & $\$ 43.8 \mathrm{M}$ & $\$ 42.9 \mathrm{M}$ & $\$ 48.1 \mathrm{M}$ \\
\hline
\end{tabular}

Source: Fielding, 2015.

\section{GOVERNANCE AND AUTONOMY}

The question of university governance is not a challenge peculiar to The College/University of The Bahamas, but is one that will exact greater attention in the transition to university. This governance question is further intensified given the nature of the evolution of the institution and its current state, as well as its geographical reality. As a national institution, 
it must innovative to provide services across an archipelago. Such an approach means engaging new ideas, operations, processes, policies and practices that break from the traditional modus operandi. As highlighted by Bethel, "overly restrictive bureaucratic procedures and processes" hampered the operation of institutional precursors to The College of The Bahamas, as evidenced for example when one examines the history of the Bahamas Teachers' College as it transitioned into and was amalgamated under the umbrella of The College (p. 62). Arguably, this development resulted in the creation of another layer of bureaucratic procedures and processes. Added to that of the Board of Education, it then included the requirements of the University of the West Indies Joint Board of Teacher Education, when in 1964, The Bahamas became a financial member of the University of the West Indies. This development, added to the governance structure as detailed in the subsequent College of The Bahamas Act (1995) in what was intended to be an otherwise autonomous institution, begs closer review.

\section{College of The Bahamas Act, 1995}

The Act of 1995 states that the President of The College "shall be appointed by the Council, with the prior approval of the Minister" (Sect. 6(1), p. 3) and "... may, with the prior approval of the Minister, remove the President from office on the ground of misconduct, inefficiency or other good cause" (Sect. 6(3), p. 3). All essential vice presidential appointments rest in the hands and at the determination of the Council. Beyond these appointments, the Council, in this Act of 1995, continues to exercise considerable control over the operation of the institution, as the "general direction and control of The College shall be vested in the Council" (Sect. 8(2), p. 4). This authority extends to policy direction, as well as to a customary fiduciary role, which may arguably be advanced, is the role of Councils/Boards of institutions of higher learning, but also extends to the welfare of the students; the property and policies of The College; and the appointment of faculty, administrative and other staff (Sect. 8(3), p. 4). Furthermore, at an even more granular operational level, the 1995 Act vested in the Council the right to:

- determine the programmes and courses of study to be pursued in The College;

- confer academic degrees and honours; grant sabbatical and other leave;

- fix fees and charges for courses of study, facilities and other services provided by The College and to reduce, waive or refund fees and charges so fixed, generally or in any particular case or class of case; and

- make regulations to direct and regulate the administration of The College (Sect. 8(3), p. 4).

The need to redefine the role of the Council/Board vis-à-vis the administrative responsibility of the daily operation of the institution, employing an appropriate shared governance model is overdue. Although not intended to be prescriptive, the joint statement on shared governance crafted by the American Association of University Professors (AAUP) and the America Council on Education (ACE) is a good beginning point (see: https:/ /www.aaup.org/report/statement-governmentcolleges-and-universities). Indeed, there is much debate currently raging in American colleges and universities regarding how this statement should be operationalized, especially as placed against the backdrop of rising financial pressure, changing pedagogical modalities, including online platforms, and the value and cost of higher education. Despite these trends, there should be a generally accepted set of principles, as argued by AAUP, that "even as the governing 
board had ultimate authority for the institution, the board should delegate the college or university's operations to the president, who in turn would delegate to the faculty primary responsibility for academic matters" (Resneck Pierce, 2014, p. 1). Despite such an approach, clearly, there is the need for all constituents to work more collaboratively to achieve common goals and in the best interest of high standards and achievement in research, teaching and service, at the heart of the academic enterprise.

As well, that shared governance means accountability for one's responsibilities and actions must not be underestimated. The need, therefore, to ensure that appropriate checks and balances are established within and throughout the requisite governance structure, is critical. This clarification of roles asserted, as the University of The Bahamas Bill, 2016 has been debated and passed by both the Parliament and the Senate of The Bahamas, and now to be enacted on Charter Day, November 10, 2016, when The College of The Bahamas transitions to the University of The Bahamas. The question now before interpreters of that Bill is whether the level of autonomy required to permit the university to function in a fashion enabling it to set a path as a genuinely independent entity, "free from undue influence from political, religious, or other external bodies" will be granted (University of The Bahamas Bill, 2016, Sect. 6(1)(c), p. 4).

\section{UNIVERSITY TRANSITION}

The 1973 Focus on the Future: White Paper on Education laid a foundation for the establishment of The College of The Bahamas, with its transition to university being forecast as early as 1975 at the institution's opening by the then Prime Minister of The Commonwealth of The Bahamas, the Rt. Hon. Lynden O. Pindling. At that time, Prime Minister Pindling predicted that "Ten years from today we will have developed the University of The Bahamas ... The College of The Bahamas will have given way to the University of The Bahamas" (Bahamas Ministry of Education, 1992, p. 51). Subsequent reports, including a UNESCO review of educational policy and planning (Reiff, Atherley, Elkrief, \& Tiburtini, 1986) highlighted plans toward this end but expressed the need for careful planning if the then modified target date of 1990 was to be met. Concerns noted at the time included the lack of resources and appropriate conditions, specifically regarding the ability to offer four-year degrees.

Since that time, the institution has expanded its offerings to include not only undergraduate, but graduate degrees, at first in partnership with international universities, but then as recently as 2010 on its own, with the introduction of a Master in Business Administration and subsequently, the Masters in Reading. Still, given the nature of the breadth of offerings, ranging from the traditional arts and sciences programmes to the professional programmes, including such majors as nursing, teacher education, business and pre-law, undergirded by the core liberal arts curriculum, the physical and human resource demands alike must be recognized and addressed proactively if the transition is to be successfully realized.

Attention to physical infrastructure, scope and reach across the archipelago, and competitive salaries for faculty, professional staff and administrators alike will likely remain challenges while holding the institution and its officers accountable for high academic standards and sound governance principles. The need for progressive university policies and organisational frameworks, including a more focused attention on the research engagement of its faculty, will feature prominently in any future development of the University of The Bahamas. More widely, a national and regional system of quality 
assurance, with reference to accreditation of higher education, has lagged, and failure to move ahead on this front is bound to pose future challenges as the transition is completed and moves into the next phases of its development, especially given the changing landscape in higher education globally.

Is the emerging University of The Bahamas, its faculty, staff and administrators, emboldened to do the work necessary to align three fundamental priorities with which all institutions of higher education must deal: excellent student learning outcomes; affordability; and financial sustainability (Bahls, 2014)? While adjusting to a rapidly changing society institutions like the University of The Bahamas must not only ensure that students exit their classrooms, research laboratories, field sites and environments with skills that best prepare them to embrace the 21 st century. As well, they must nurture and encourage innovative thinking and critical mind-sets that result in graduates able to solve the most pressing challenges of today, nationally, regionally, and indeed globally, pointing up the importance of informing a national development plan.

\section{CONCLUDING REMARKS}

President Emerita, Dr Keva M. Bethel's contribution to leadership at the helm of The College of The Bahamas during its extended developmental years, is unquestionable. It is unfortunate that she left us before being able to complete this last assignment requested by the institution, namely, writing a book on the history of post-secondary education in The Bahamas with particular reference to the history of The College of The Bahamas. The progress report completed by Dr Bethel does, however, provide an excellent blueprint for an on-going analysis of the prerequisites required to enable a higher education institution to function utilising principles of best practice. Hers is an assignment that is well worthy of completion, along with a subsequent chapter, the establishment, launch and history of the University of The Bahamas, conceivably ready to be crafted - an honour to her legacy.

\section{REFERENCES}

Bahamas Ministry of Education and Culture. (1973). Focus on the future: White paper on education. Nassau, Bahamas: Author.

Bahamas Ministry of Education. (1992). Master plan for post-secondary education in the Bahamas. Nassau, Bahamas: Author. Retrieved from http://ufdcimages.uflib.ufl.edu/AA/00/01/3 2/97/00001/Master_Plan_for_Post_Second ary_Education_in_the_Bahamas_1991.pdf

Bahamas Ministry of Education. (1994). National Task Force on Education. Nassau, Bahamas: Author.

Bahls, S. C. (2014). Shared governance in times of change: A practical guide for universities and colleges. Washington, D.C.: AGB Press.

Bethel, K. M. (1981). Perceived effectiveness of teacher education programs in The Bahamas. (Unpublished doctoral dissertation). University of Edmonton, Alberta.

Bethel, K. M. (2007). Final report of the Ad hoc Advisory Committee on Governance. Nassau, Bahamas: College of The Bahamas. Retrieved from http://www.cob.edu.bs/DOCS/Governance Rpt_Jun2007.pdf

Bethel, K. M. (2016). Progress report on the project: Purpose and promise: A history of the evolution of higher education in The 
Bahamas, with particular reference to the history of The College of The Bahamas. The International Journal of Bahamian Studies, 22, 61-73. http://dx.doi.org/10.15362/ijbs.v22i0.264

Christie, P. (2016). Bahamas PM 2016-17 budget communication. Retrieved from http://www.thebahamasweekly.com/publis h/bis-news-updates/Bahamas_PM_ Delivers_the_2016_17_Budget_Communi cation48498.shtml

College of The Bahamas Act, Chapter 48, Bahamas, 1995. Retrieved from http://www.cob.edu.bs/DOCS/COBACTN O15_1995.pdf

College of The Bahamas. (2007). Marine and Environmental Studies Institute (MESI) [web page]. Retrieved from http://www. cob.edu.bs/Research/MESI.php

College of The Bahamas. (2009). College to university: Strategic plan 2009-2019. Nassau, Bahamas: Author. Retrieved from http://www.cob.edu.bs/Administration/Stra tegicPlan.pdf

College of The Bahamas. (2010). About The College of The Bahamas: History [web page]. Retrieved from http://www.cob.edu.bs/About/History.php

Fielding, W. J. (2014). The impact of college graduates on Bahamian society: With emphasis on graduates from The College of The Bahamas. International Journal of
Bahamian Studies, 20(2), V 1-11. http://dx.doi.org/10.15362/ijbs.v20i2.209

Fielding, W. J. (2015). Public support for The College of The Bahamas. Unpublished manuscript, Office of Institutional Planning, The College of The Bahamas.

Indiana University Center for Postsecondary Research. (2016). FSSE: Faculty survey of student engagement [web page]. Retrieved from

http://fsse.indiana.edu/html/about.cfm

Reiff, H., Atherley, L. G., Elkrief, A., \& Tiburtini, R. (1986). Education, training and society: Sector review, recommendations for development and project identification: The Commonwealth of the Bahamas. Paris: UNESCO.

Resneck Pierce, S. (2014). Governance reconsidered: How boards, presidents, administrators, and faculty can help their colleges thrive. San Francisco: JosseyBass.

Sutton, H. (2016). Crime and violence in The Bahamas. Washington, DC: InterAmerican Development Bank http://dx.doi.org/10.18235/0000334

University of The Bahamas Act, 2016. Retrieved from http://www.bahamas.gov .bs/wps/wcm/connect/b1100ce8-56bd46aa-b9ca-a0c616fd48c4/university+of+ The+Bahamas+2016.pdf?MOD=AJPERES 